\title{
EXPOSITION OF NEHEMIAH'S LEADERSHIP MODEL; A Spiritual and Transformational Leadership Approach
}

\author{
Asnita Basir Leman \\ Evangelical Theological Seminary of Indonesia - Jakarta \\ asnitaleman@yahoo.com
}

\begin{abstract}
Many world leadership motivators use the Bible's principles and applied them in the secular area, and they are very success. Ironically, when christians want to emulate that success and reuse those principles in spiritual leadership of the church, it turns out that in the process of "re-use" and "re-pack" someone has been eliminated, Christ is no longer be the center of that leadership. This article aims to present an exposition of Nehemiah's leadership model, conduct a comparative analysis based on spiritual leadership and transformational leadership theory, then synthesize according to theological context and its current application concepts based on the worldview christian. The results of the research are expected to be an inspiration for the christian leadership holistically.
\end{abstract}

Keywords:Nehemiah, spiritual leadership, transformational, worldview christian.

\section{INTRODUCTION}

Changes in the situation, cultural and technological developments are forces that emerge and accelerate exponentially society and social institutions change. This fact is always followed by an indication of the urgent need for a relevant leadership model, according to the needs and conditions of the era. The Bible records the history and leadership roles of each generation according to the changes that have occurred over time. It is a universal reality of human life in the world, but on the other side it is part of God's eternal plan for mankind, specifically through the historical and prophetic chronology of the nation of Israel. When the leader goes right, the Israelites are preserved, but when the leader deviates, Israel suffers. The biblical principles of leadership seem to be quite in line with universally applicable leadership values. This writing shows that the two are not separate, but in parallel and even integrated.

\section{Give us a king !}

When Samuel was old and appointed his two incompetent and evil 
sons to be judges, the Israelites asked a king to lead them like other nations. Is this wrong ? Not really, because God had promised that from Abraham would come kings (Gen 17:6, 16) and repeated the promise to Jacob (Gen 35:11). In the book of Deuteronomy it is written that when Israel has occupied and dwelt in the promised land, then Israel may appoint a king, provided that the king is chosen by the LORD, the God of Israel. But when Israel asked Samuel for the king, God who judged the heart said to Samuel, "Indeed it is I they have rejected." Israel is not guilty when asking for a king, but the motivation of those who reject God's leadership, followed by Israel choosing a leader that is not chosen by God, but from human judgment. The Lord then reminded Israel of the rights of the king who would rule over them. The word "right" uses miš-pāt- procedures, rules (I Sam 8:9). The same word is used at Habakkuk 1:4 "that is why justice is turned upside down",

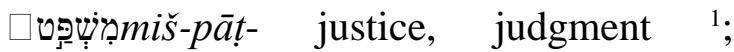
describes the events of Nebuchadnezzar the

\footnotetext{
${ }^{1}$ Strong's Hebrew 4941: 1) judgment, justice, ordinance, 1a) judgment, 1a1) act of deciding a case, 1a2) place, court, seat of judgment, 1a3) process, procedure, litigation (before judges), 1a4) case, cause (presented for judgment, 1a5) sentence, decision (of judgment), 1a6) execution (of judgment), 1a7) time (of judgment), 1b) justice, right, rectitude (attributes of God or man), 1c) ordinance, 1d) decision (in law), 1e) right, privilege, due (legal), 1f) proper, fitting, measure, fitness, custom, manner, plan.
}

king of Babylon's invasion of Judah, and the hordes of the Chaldeans, Aramites, Moabites, Ammonites who attacked Jehoiakim king of Judah. God sent them to punish Judah for the sins of Manasseh (II Kings 24:2-4). The Babylonian king returned to destroy Jerusalem and the temple in 586 BC. Justice appears upside down, because the wicked surround the righteous, and not the other way around. After 70 years of Babylonian exile, God kept His promise and brought Israel back to the promised land. Here the role and model of Nehemiah's leadership will be discussed, where the central theme of biblical leadership cannot be separated from God's global plan and vision.

\section{An irony of leadership}

A French proverb says l'histoire se repete, history will repeat its story. The book of Ecclesiastes writes, what was there will be again; there is nothing new under the sun (Ecc 1:9). Every era has important and urgent leadership needs according to the situation and conditions of the times. But make no mistake, because the principles and concepts of biblical leadership have not changed, even tough its application and implementation need to accommodate the changing cultural society and technological developments that are happening now. One of the phenomena 
that is growing rapidly today is information and communication technology, through the internet network, aspects of space and time are almost no longer an obstacle. However, the internet also provides access to a variety of unhealthy information, a wrong attitude if you then think that the internet is something that is destructive and needs to be avoided. Failure to distinguish between principles and concepts and their adaptation is catastrophic. Not accommodating the current application is to be lagging behind, but application without correct principles and concepts will causes error and collapse.

Dr. Louis Fry, a professor of organizational theory, a behavior leadership expert whose work has been cited by nearly twelve thousand times, examines spiritual leadership and the spirituality of the world of work in relation to organizations that are open to learning.It is said that the trend of accelerating the spirituality of the world of work and the paradigm of learning organizations goes hand in hand, with the main issues being the quality and process of strategic leadership, leadership patterns in empowered teams and personal leadership that facilitates. Organizations that do not make changes to incorporate spiritual values into the world of work may fail to make the transitionto the learning organization paradigm necessary for success in the 21 st century. ${ }^{2}$. These fields are new research areas in the early stages of development, so they do not yet have a strong theoretical framework and research findings. However, most of the organizational and leadership theories proposed in this field derive from Western religious theology and its ethical practices and leadership values. ${ }^{3456}$ Vision and core values of humility, altruistic love and honesty ${ }^{7}$ common to all ethical principles and values-based approaches to leadership. Servant leadership states that servant leaders unite the meaning of service and spiritual values that create a positive impact on the organization ${ }^{8}$. Even in the US military area, Major Slotnick submitted a thesis for a military master's degree on spiritual leadership, openly stating that his thesis explored the Bible and theological books as sources of insight into human

\footnotetext{
${ }^{2}$ Louis W. Fry, "Toward a Theory of Spiritual Leadership,” Leadership Quarterly 14, no. 6 (2003): 693-727.

${ }^{3}$ Henry T Blackaby and Richard Blackaby, Spiritual Leadership - Moving People On To God's Agenda (Nashville, Tennessee, 2006).

${ }^{4}$ J. Oswald Sanders, Spiritual Leadership (Chicago: Moody Press, 1986), https://pubs.acs.org/doi/10.1021/acsami.9b03822. ${ }^{5}$ Stephen R Covey, Principle-Centered Leadership (New York: RosettaBooks, 1991).

${ }^{6}$ Stephen R Covey, The Seven Habits of Highly Effective People (New York: Free Press, 2004). ${ }^{7}$ Huston Smith, The World's Religions, 2nd ed. (San Fransisco: Harper, 1991).

${ }^{8}$ Robert K. Greenleaf, The Servant as Leader (Westfield, IN: The Greenleaf Center, 2008).
} 
spirituality. ${ }^{9}$ But all agreed to exclude aspects of faith and religion. Considering faith is a personal issue and decision that is difficult to measure and relates to life after death, while religious aspects are related and tied to individual traditions and procedures, thus becoming less relevant to the issue of the growing need for universal secular leadership. So that the theistic nature of God is defined in terms of ethical character and values through the principles of love and justice, which have become the basic structure that is actively working in the process of development. ${ }^{10}$. Whereas ethical values such as integrity, honesty, justice and caring which have the influence on followers and the environment are the fruits of character that cannot be separated from spirituality of the leader. They are known for the ability to possitively impact peers and followers from connectedness and good dyadic relationships. ${ }^{11}$ Whilemany world leaderssucceed in implementing biblical principles in the secular world but has excluded the essence of God of the Bible, thechurch as heir to the mandate of God of

\footnotetext{
${ }^{9}$ Michael D Slotnick, "Spiritual Leadership, How Does The Spirit Move You?," Distribution (B.S United States Military Academy, West Point, New York, 1992).

${ }^{10}$ Fry, "Toward a Theory of Spiritual Leadership."

${ }^{11}$ Robert Ball, "Spiritual Leadership : An Exegetical Examination of Daniel' s Spiritual Leadership Style," The American Journal of Biblical Theology 22, no. 41 (2021): 1-11.
}

the Bible, unconsciously turns away and learns from leadership theories that have explored biblical values but stripped away the essence of divinity. So ironic.

\section{RESEARCH METHODS}

\section{Reference Framework}

This writing uses qualitative research methods with the concept of literature study, which combines several methods and analytical techniques to develop a model and argument that can be an inspiration for further research. The discussion of Nehemiah's leadership exposition is carried out diachronically from the integration of historical, textual and theological analysis, and synchronously through a structuralism approach from the integration of canonical narrative function analysis ${ }^{12}$ and analysis of actential roles. ${ }^{13}$ The diachronic exposition will also examine the roles and qualifications of leadership based on spiritual and transformational leadership theories to prove that biblical leadership principles are universally relevant. The whole discussion of Nehemiah's leadership exposition is concluded through an intertextual approach and the principle of

\footnotetext{
${ }^{12}$ Daniel Patte, What Is Structural Exegesis?, 2nd ed. (Philadelphia: Fortress Press, 1979).

${ }^{13}$ Algirdas Julien Greimas, On Meaning: Selected Writings in Semiotic Theory (Minneapolis: The University of Minnesota Press, 1987).
} 
progressive messianic revelation to

understand its biblical meaning and

christian application.

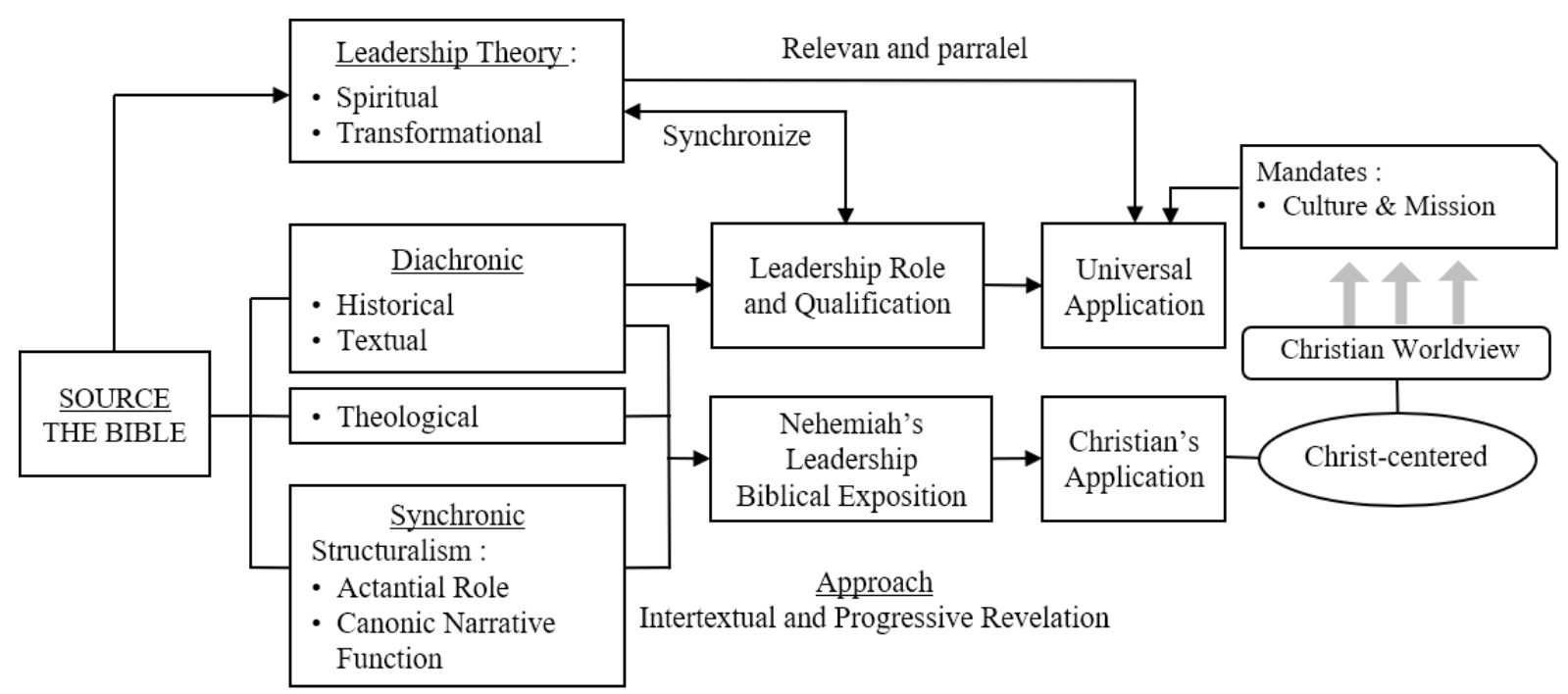

Figure 1. Research Methods Schematic and Frame of Reference

The research aims to show that universal application that is applied directly to church leadership can shift Christian faith towards liberalism and humanism motivations, whereas direct Christian application in the secular world has so far been considered as religious fanaticism or an "too spiritual" attitude. The gap makes Christians trapped in the two contrasts of life in the world and the church in the dimensions of space and time, when they are in church or in everyday life and on Sundays or on ordinary days. A life in double standards, with threats of lukewarm faith, worldliness, hypocriticism and even apostasy. ${ }^{1415}$ From here the culture and mission mandated by God became the basis of His divine transformation plan for humans. This is where Christianity should be based.

\section{LITERAL REVIEW \& DISCUSSION}

\section{Spiritual Leadership and}

\section{Transformational Leadership Theory}

The disruption of the global

\footnotetext{
${ }^{14}$ Norman L. Geisler and R. C. Sproul, Explaining Biblical Inerrancy: Official Commentary on the ICBI Statements (Matthews, NC: Bastion Books, 2013), http://bastionbooks.com/shop/explainingicbi/. ${ }^{15}$ Del Tackett, "What's a Christian Worldview ?," last modified 2006,

https://www.focusonthefamily.com/faith/whats-achristian-worldview/.
} 
Theological Journal Kerugma

E-ISSN: 2622-1039

P-ISSN: 2621-8038

situation and the rapid development of technology in this century have prompted the need for various changes in society, institutions, including leadership area. This reality demands a more holistic leadership covering the fundamental areas of human existence, the body, mind, heart and spirit. And of course requires a paradigm shift in a direction that is very different from the previous patterns and traditional bureaucracies which were centralized, standardized with fear-based formal relations that have dominated since the industrial revolution era. ${ }^{16}$ A new paradigm shift that is radically different; driven by love, caring, intrinsic motivation, service orientation, empowerment base and synergy team, accommodating diversity, innovative, global view, inter-institutionals mutualistic network even with competitors. ${ }^{17}$ Dr. Louis Fry presents spiritual leadership theorywith

\footnotetext{
${ }^{16}$ Russ S. Moxley, Leadership and Spirit (San Fransisco, CA: Jossey-Bass, 1999).

${ }^{17}$ Deborah Ancona et al., Managing for the Future Organizational Behavior \& Processes, Routledge, 3rd ed. (Mason,. OH: South Western Cengage Learning, 2009).
} 
Theological Journal Kerugma

E-ISSN: 2622-1039

P-ISSN: 2621-8038

the argument that the spiritual aspect is a basic need of all people, both leaders and followers. So, a healthy spiritual condition will be able to grow commitment and productivity. Previous leadership theories emphasized the physical, mental or emotional aspects of human interaction in institutions and ignored the spiritual aspects. While the spiritual aspects include values, behavioral attitudes and more to intrinsic personal motivation, where they build spirituality through calling (calling) and membership (membership). Spiritual leadership builds a vision in which members experience a sense of calling and an altruistic and compassionate membership atmosphere. ${ }^{18}$

${ }^{18}$ Fry, "Toward a Theory of Spiritual Leadership." 


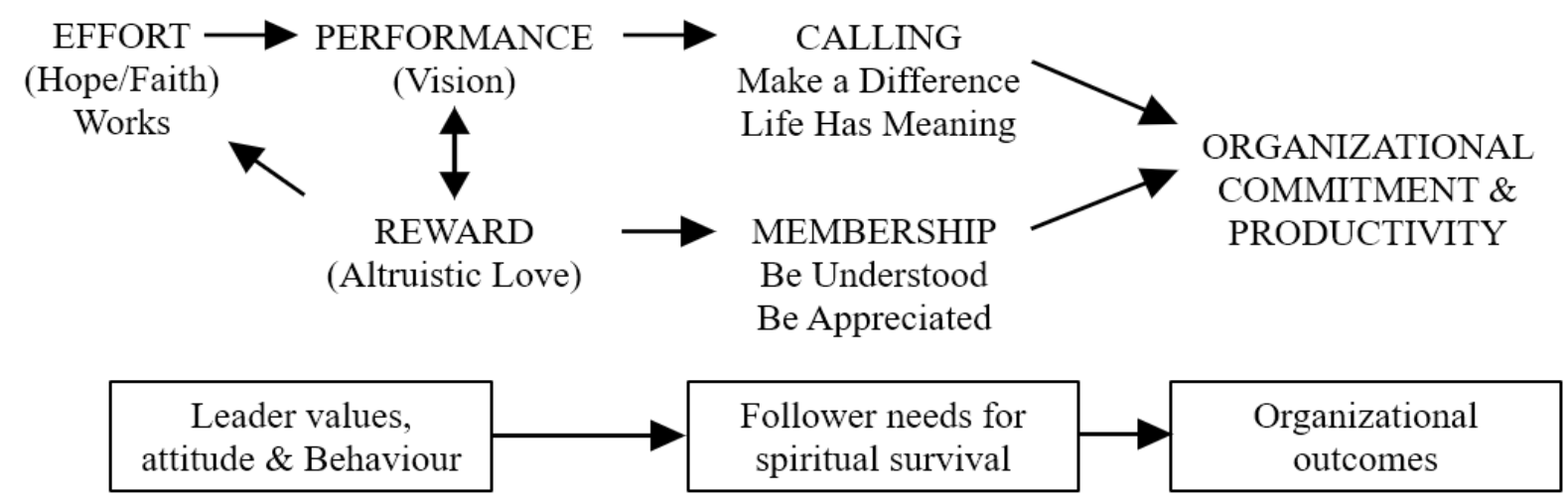

Figure 2. Causal Model of Sipitual Leadership ${ }^{19}$ 
Dr. Fry argues that leadership is the basis of a person's motivation to change. The shared vision of the leader is a more meaningful calling for life for members, and as a reward is an attitude of acceptance of members in an environment that is influenced with altruistic love. The spiritual leadership of the secular world excludes disaggregated aspects of religion and introduces a universal definition of divinity as a higher power and continuum. This concept is considered capable of accommodating all understandings of God, whether atheistic, humanistic, theistic and pantheistic. ${ }^{20}$ In his writing, Dr. Fry also examines the theory of leadership based on religion and values which emphasizes that leaders must live the core values of their beliefs and impart to followers through vision, values and personal behavior. ${ }^{21}$.The following table shows the qualifying aspects of spiritual leadership ${ }^{22}$

\footnotetext{
${ }^{20}$ Smith, The World's Religions.

${ }^{21}$ Fry, "Toward a Theory of Spiritual Leadership."

${ }^{22}$ Ibid.
} 


\begin{tabular}{|lll|}
\hline Vision & Altruistic Love & Hope / Faith \\
\hline - Has broad appeal to key stakeholders. & - Forgiveness & - Durability \\
- Define goals and stages. & - Kind & - Perseverance \\
- Demonstrate ideals. & - Integrity & - Doing duty \\
- Encourage hope and confidence & - Empathy/Compassion & - Pursuing targets/goals \\
- Setting the standard of excellence & - Honesty & - Hope for reward and \\
& - Patience & victory \\
& - Travery & \\
\hline
\end{tabular}

Table 1. Qualifications of spiritual leadership

The vision refers to a picture of the future with statements why people should strive to get there. A clear and convincing vision, gives a brief picture of what and where will be in the short to long term period future, thus providing guidance on the general direction of change, more detailed decisions, coordination of actions of many people. The vision describes the journey of the institution and why leaders and followers do it. It must motivate everyone, build commitment, give meaning to all works and by setting standards of performance and qualifications ${ }^{23}$. The mission refers to the principles, values, culture and reasons for the existence of the institution to achieve the vision. For the theory of spiritual leadership, the application of altruistic love (selfless) is shown as a sense of wholeness, harmony

\footnotetext{
${ }^{23}$ Richard L Daft and Robert H Lengel, Fusion Leadership : Unlocking the Subtle Forces That Change People and Organizations (Oakland, CA: Berrett-Koehler Publisher, 2000).
}

and well-being through a sense of care, concern and respect for oneself and others. In this love are values of patience, kindness, not jealousy, forgiveness, humility, selflessness, self-control, trust, loyalty and truth. (Cf. Love, I Cor. 13:4-8; fruit of the Spirit, Gal 5:22-23). The medical world and the field of psychology have studied and confirmed that altruistic love has the power to overcome the destructive influence of four main areas of negative emotions, namely; 1) fear (including anxiety, worry), 2) anger (including hostility, resentment, envy, hatred), 3) failure (including hopelessness, depression, guilt, self-harm) and 4) pride (including, prejudice, selfishness, greed, pride) (Cf. works of the flesh, Gal 5:19-21; Fear, I John 4:18 ). Love is the power to reject fear, becomes the basis for healing 
negative emotions ${ }^{24}$. Webster's Dictionary defines faith as, "certainty of things hoped for, belief in things not seen." (Cf. Heb. 11:1). Hopeis a wish with the hope of fulfillment, but faith adds firm certainty to something for which there is no evidence. Faith is based on values, attitudes and behaviors that show certainty and are expected to happen. People with hope and faith who have a clear vision of where they are going and how to get there, they are able to face opposition, endure hardships and suffering to achieve their goals. Faith that is truly proven through action or work, often used the metaphor of "competing" to show faith that works or acts. The competition of faith is like running a marathon which requires self-control, perseverance, an attitude of endurance, ${ }^{25}$. Spiritual leadership says, thus hope and faith are sources for confidence that the vision, goals and mission of the institution or organization will be fulfilled. Spiritual leadership has applied Bible principles and values and Christian teachings, but has excluded Christ who reveals the true God of the Bible. Utilizing the "body" but ignoring the "Head" that is the Lord Jesus Christ.

\footnotetext{
${ }^{24}$ Charles Livingstone Allen, The Miracle of Love (Grand Rapids: Fleming H Revell Co., 1972).

${ }^{25}$ John MacArthur, In the Footsteps of Faith: Lessons from the Lives of Great Men and Women of the Bible (California: Crossway Books, 1998).
}

Transformational leadership is also motivation-based leadership. Bass and Riggio put forward the concepts of transactional \& transformational leadership to provide a theoretical framework and categorization in its aspects. ${ }^{26}$ Transactional leadership underlies most leadership models with a focus on exchanges between leaders and followers on the basis of extrinsic motivation. Leaders achieve their goals and followers receive external compensation for their contributions. Transactional leadership is at the heart of the management process aimed at keeping performance running smoothly and efficiently. Emphasis is placed on regulatory control and compliance, and maintaining stability in institutional performance rather than promoting change. Follower motivation is carried out by leaders by clarifying expectations and meeting their external needs, followers build self-confidence and morale to be more productive. ${ }^{27}$ In contrast, transformational leadership has an intrinsically based motivational process in which leaders engage followers to create relationships that build both levels of effort and moral aspirations. Transformational

\footnotetext{
${ }^{26}$ Bernard M Bass and Ronald E Riggio, Transformational Leadership, 2nd ed. (New Jersey, London: Lawrence Erlbaum Associates, 2006).

${ }^{27}$ Richard L Daft, The Leadership Experience, 4th ed. (Mason: Thomson South-Western, 2008).
} 
Theological Journal Kerugma

E-ISSN: 2622-1039

P-ISSN: 2621-8038

leadership sees charisma as needed but not central to leadership. Charismatic leadership is centered on the leader's personality, while transformational leadership pays attention to the needs and motives of followers beyond the leader's own interests, inspires followers, supports them to develop to reach their maximum potential for the common good. ${ }^{28}$

${ }^{28}$ Francis J. Yammarino, "Transforming Leadership Studies: Bernard Bass' Leadership and Performance beyond Expectations," The Leadership Quarterly 4, no. 3-4 (January 1, 1993): 379-382. 


\begin{tabular}{|ll|}
\hline \multicolumn{1}{|c|}{ Leadership Aspect } & Ethical considerations: \\
\hline Aspects: & Transactional Leadership \\
\hline - Tasks and work & - Whether the purpose and method of implementation do not violate \\
- Wage system (reward) & moral ethics. \\
& - Are incentives or sanctions respecting conscience and not \\
& suppressing freedom (direct or indirect coercion). \\
- Consequence & - Selfless vs sincere, respecting all related regardless of position \\
- Reasonable process & - Impartial conflict and claims resolution process \\
\hline Aspects: & Transformational leadership \\
\hline - Impartial idealism & - Do you dominate and manipulate or not \\
- Motivational inspiration & - Is it true empowering and actualizing members or not \\
- Intellectual stimulation & - Is the leader program open for development or closed \\
- individual care & - Are members treated as ends/means solely or \\
& their personal dignity and uniqueness are accepted and valued \\
\hline
\end{tabular}

Table 2. Moral aspects of transactional and transformational leadership

The table shows the ethical considerations of transactional and transformational leadership with value aspects that can be measured by the Multifactor Leadership Questionnaire (MLQ). ${ }^{29}$ This study does not use MLQ questionnaire but will compare aspects of content analysis with Nehemiah's leadership narrative.

The most important role of transformational leadership is to describe and communicate a vision that makes followers believe and have faith in the goals of transformation so that they are able to make it happen according to the struggle. Because control and change are important processes in transformation, effective leaders must be able to realize their roles both transactionally and

\footnotetext{
${ }^{29}$ Bass and Riggio, Transformational Leadership.
}

transformationally in accordance withsituations and needs, so that both transactional and transformational leadership are seen as an integrated rather than separate continuum ${ }^{30}$. In general, leadership theories based on intrinsic and extrinsic motivation are related to one another and are used or reviewed according to needs and conditions. Transactional and transformational leadership integration components ${ }^{31}$.

\footnotetext{
${ }^{30}$ Yammarino, "Transforming Leadership Studies: Bernard Bass' Leadership and Performance beyond Expectations."

${ }^{31}$ Bernard M. Bass et al., "Predicting Unit Performance by Assessing Transformational and Transactional Leadership," Journal of Applied Psychology 88, no. 2 (2003): 207-218.
} 


\begin{tabular}{|l|l|}
\hline Leadership Components: & Explanation in application: \\
\hline - Charismatic (K) & - Influencing charismatically and values \\
- Exemplary (T) & - Be a role model in attitude and behavior \\
- Inspirational (I) & - Inspire a shared vision and mission \\
- Active (A) & - Enabling people to be innovative and creative \\
- Accommodating (M) & - Accommodating personal needs \\
\hline
\end{tabular}

Table 3. Moral Aspects of Transactional and Transformational Leadership

Research on the exposition of Nehemiah's leadership model, will be reviewed from an integrative approach with spiritual leadership theory that has relevance from the source of the values used, as well as transformational leadership theory that considers the scope of Nehemiah's vision and context in the Bible.

\section{Nehemiah's Leadership Exposition}

\section{Historical Review}

After seventy years of Israel's exile to Babylon since the first deportation in $605 \mathrm{BC}$, the LORD moved the heart of Cyrus II king of Persia to fulfill the words spoken by the prophet Jeremiah (Jer 29:10; Ezra 1:1-4). In $538 \mathrm{BC}$ he ordered the rebuilding of the temple in Jerusalem, so the first group of Israelites, the tribe of Judah and the priests, returned. In 536 BC they built an altar and began the construction of the temple, led by Zerubbabel son of Shealtiel and the priest Yesua son of Jozadak (Ezra 3:1-8). Their opponents, the inhabitants of the land of Canaan, tried to weaken the hearts of the people of Judah and make them afraid to build, so that the construction of the temple of God was stopped in 530-520 BC during the time of Darius I king of Persia (Ezra 4). The prophets Haggai and Zechariah son of Iddo prophesied in the name of the God of Israel, So Zerubbabel and Jeshua began to build the temple. The eyes of God watched the elders of the Jews so that they were not forced to stop, until a letter of response from King Darius was sent back allowing the construction of the temple to be continued until it was completed in 516 BC (Ezra 6). In 458 BC, under King Artaxerxes I, the second group with Ezra returned to Jerusalem (Ezra 7:6-9). The Jews gathered, Ezra led them to confession and the separation of the practice of intermarrying with the natives made the holy seeds mixed (Ezra 9:1-10:44). In 445 BC, Nehemiah in the castle of Susan received word that the walls of Jerusalem had been torn down and its gates were on fire. He went to King Artaxerxes I and with a group of three Jews returned to Jerusalem (Neh 2:1-11). The eyes of God watched the 
elders of the Jews so that they were not forced to stop, until a letter of response from King Darius was sent back allowing the construction of the temple to be continued until it was completed in $516 \mathrm{BC}$ (Ezra 6). In 458 BC, under King Artaxerxes I, the second group with Ezra returned to Jerusalem (Ezra 7:6-9). The Jews gathered, Ezra led them to confession and the separation of the practice of intermarrying with the natives made the holy seeds mixed (Ezra 9:1-10:44). In 445 BC, Nehemiah in the castle of Susan received word that the walls of Jerusalem had been torn down and its gates were on fire. He went to King Artaxerxes I and with a group of three Jews returned to Jerusalem (Neh 2:1-11). The eyes of God watched the elders of the Jews so that they were not forced to stop, until a letter of response from King Darius was sent back allowing the construction of the temple to be continued until it was completed in 516 BC (Ezra 6). In 458 BC, under King Artaxerxes I, the second group with Ezra returned to Jerusalem (Ezra 7:6-9). The Jews gathered, Ezra led them to confession and the separation of the practice of intermarrying with the natives made the holy seeds mixed (Ezra 9:1-10:44). In 445 $\mathrm{BC}$, Nehemiah in the castle of Susan received word that the walls of Jerusalem had been torn down and its gates were on fire. He went to King Artaxerxes I and with a group of three Jews returned to Jerusalem (Neh 2:1-11). until King Darius's response letter was sent back allowing the construction of the temple to continue until it was completed in 516 BC (Ezra 6). In 458 BC, under King Artaxerxes I, the second group with Ezra returned to Jerusalem (Ezra 7:6-9). The Jews gathered, Ezra led them to confession and the separation of the practice of intermarrying with the natives made the holy seeds mixed (Ezra 9:1-10:44). In 445 BC, Nehemiah in the castle of Susan received word that the walls of Jerusalem had been torn down and its gates were on fire. He went to King Artaxerxes I and with a group of three Jews returned to Jerusalem (Neh 2:1-11) until King Darius's letter was sent back allowing the construction of the temple to continue until it was completed in 516 BC (Ezra 6). In 458 BC under King Artaxerxes I, the second group with Ezra returned back to Jerusalem (Ezra 7:6-9). The Jews gathered, Ezra led them to confession and the separation of the practice of intermarrying with the natives made the holy seeds mixed (Ezra 9:1-10:44). In 445 BC, Nehemiah in the castle of Susan received word that the walls of Jerusalem had been torn down and its gates were on fire. He went to King Artaxerxes I and with a group of three Jews returned to Jerusalem 
(Neh 2:1-11), the second group with Ezra returned to Jerusalem (Ezra 7:6-9). The Jews gathered, Ezra led them to confession and the separation of the practice of intermarrying with the natives made the holy seeds mixed (Ezra 9:1-10:44). In 445 BC, Nehemiah in the castle of Susan received word that the walls of Jerusalem had been torn down and its gates were on fire. He went to King Artaxerxes I and with a group of three Jews returned to Jerusalem (Neh 2:1-11). the second group with Ezra returned to Jerusalem (Ezra 7:6-9). The Jews gathered, Ezra led them to confession and the separation of the practice of intermarrying with the natives made the holy seeds mixed (Ezra 9:1-10:44). In 445 BC, Nehemiah in the castle of Susan received word that the walls of Jerusalem had been torn down and its gates were on fire. He went to King Artaxerxes I and with a group of three Jews returned to Jerusalem (Neh 2:1-11).

Ezra 1:1 - Nehemiah 7:3 Return - Reconstruction

\begin{tabular}{|c|c|l|}
\hline 538-7 BC & Zerubbabel & The first group; come back to rebuild the temple \\
\hline 458 BC & Ezra & The second group; back to restore God's people \\
\hline 445 BC & Nehemiah & The third group; back to build the walls of Jerusalem \\
\hline \multirow{2}{*}{ Nehemiah 7:4-12:43 Renewal - Reformation } \\
\hline \multirow{2}{*}{ 445-4 BC } & \multirow{2}{*}{ Nehemiah } & Neh 7:4-73a Community renewal \\
\cline { 3 - 3 } & & Neh 7:73b-10:39 Renewal of the covenant \\
\cline { 3 - 4 } & Neh 11:1-12:43 God's joyful ordination \\
\hline
\end{tabular}

Table 4. Structure of the book of Ezra Nehemiah according to Throntveit

Mark Throntveit divides the structure of the book of Ezra Nehemiah into two main parts, namely: 1) Return - Reconstruction and 2) Renewal - Reform, the second part is called theological event. ${ }^{32}$ The tabernacle and temple function as God's own dwelling place, the presence of God who "camps" among His people and fellowshipes with them in the covenant grace of His love is the

\footnotetext{
${ }^{32}$ Mark Throntveit, Ezra-Nehemiah Interpretation Bible Commentary, ed. James Luther Mays (Louisville, Ky: John Knox Press, 1992).
}

most central and very important theme in the Bible. ${ }^{33}$. Nehemiah's leadership was inseparable from the theological context of the Temple and the nation of Israel.

\section{Textual Overview}

The world needs good leaders, but more importantly the world needs godly leaders

\footnotetext{
${ }^{33} \mathrm{~J}$ Daniel Hays, The Temple and the Tabernacle. A Study of God's Dwelling Places from Genesis to Revelation (Grand Rapids, MI: Baker Books, 2016).
} 
Theological Journal Kerugma

E-ISSN: 2622-1039

P-ISSN: 2621-8038

34

${ }^{34}$ Christopher R Losey, The Portrait of a Godly Leader (Creekside, California: Institute of Disciple Making, 2012). 
Theological Journal Kerugma

E-ISSN: 2622-1039

P-ISSN: 2621-8038

\begin{tabular}{|c|c|c|c|c|c|}
\hline Paragraph & Leadership qualification & & Paragraph & Leadership qualification & \\
\hline $1: 1-3$ & concerned about the nation's & M & $2: 19-20$ & Protective and empowering & A \\
\hline $1: 4 a$ & difficulties & M & $3: 1$ & team and situation monitoring & M \\
\hline $1: 4 b-6$ & have empathy & $\mathrm{K}$ & $3: 1$ & show appreciation & M \\
\hline $1: 6 a$ & have a spiritual life & $\mathrm{T}$ & $3: 1-32$ & accurate with documentation data & A \\
\hline $1: 6 b-7$ & humble & $\mathrm{T}$ & $4: 1-14$ & full of motivation & I \\
\hline $1: 8-10$ & openly admit mistakes & $\mathrm{K}$ & $4: 12,13$ & a good listener & M \\
\hline $1: 11$ & have faith & $\mathrm{K}$ & $4: 13-23$ & flexible and adaptable & A \\
\hline $2: 1,2$ & live by faith & $\mathrm{T}$ & $4: 12-23$ & protective & M \\
\hline $2: 3 a, 5$ & self control & M & $4: 19,20$ & brave and determined & $\mathrm{I}$ \\
\hline $2: 3$ & be respectful & $\mathrm{T}$ & $5: 1-13$ & be fair & $\mathrm{T}$ \\
\hline $2: 4$ & have patience & $\mathrm{K}$ & $5: 12 \mathrm{a}$ & solve the problem & A \\
\hline $2: 5$ & praying/relying on God & M & $5: 14-16$ & heart that serves & $\mathrm{T}$ \\
\hline $2: 6-8 \mathrm{a}$ & communicator/negotiator & I & $5: 16$ & cooperative and team work & A \\
\hline $2: 8 b-10$ & visionary planner & $\mathrm{K}$ & $5: 15-19$ & spiritual motivation - fear of God & $\mathrm{K}$ \\
\hline $2: 10$ & relationship and networking & $\mathrm{A}$ & $6: 1-14$ & stick to priorities, work through & A \\
\hline $2: 12-15$ & perspective & $\mathrm{T}$ & $7: 1,2$ & sensitive to the competence of the & A \\
\hline $2: 12$ & realistic with challenges & $\mathrm{K}$ & $8: 8-12$ & team & 4 \\
\hline $2: 12 b$ & selfless hard worker & $\mathrm{T}$ & $12: 27-31$ & celehrating succ & \\
\hline $2: 13-15$ & wise/keep secret & $\mathrm{A}$ & $8-13$ & celebrating succe & $\mathrm{K}$ \\
\hline $2: 16-18$ & $\begin{array}{l}\text { can be trusted } \\
\text { meticulous planner } \\
\text { have/able to vision }\end{array}$ & I & $13: 30-31$ & $\begin{array}{l}\text { focus on the spiritual standard of } \\
\text { God's law } \\
\text { structured and organized }\end{array}$ & A \\
\hline
\end{tabular}

Leadership Components: Charismatic (K), Exemplary (T), Inspirational (I), Actuative (A), Accommodative (M) Note: Qualifications may include several leadership components.

Table 5. Nehemiah's transformational leadership qualifications
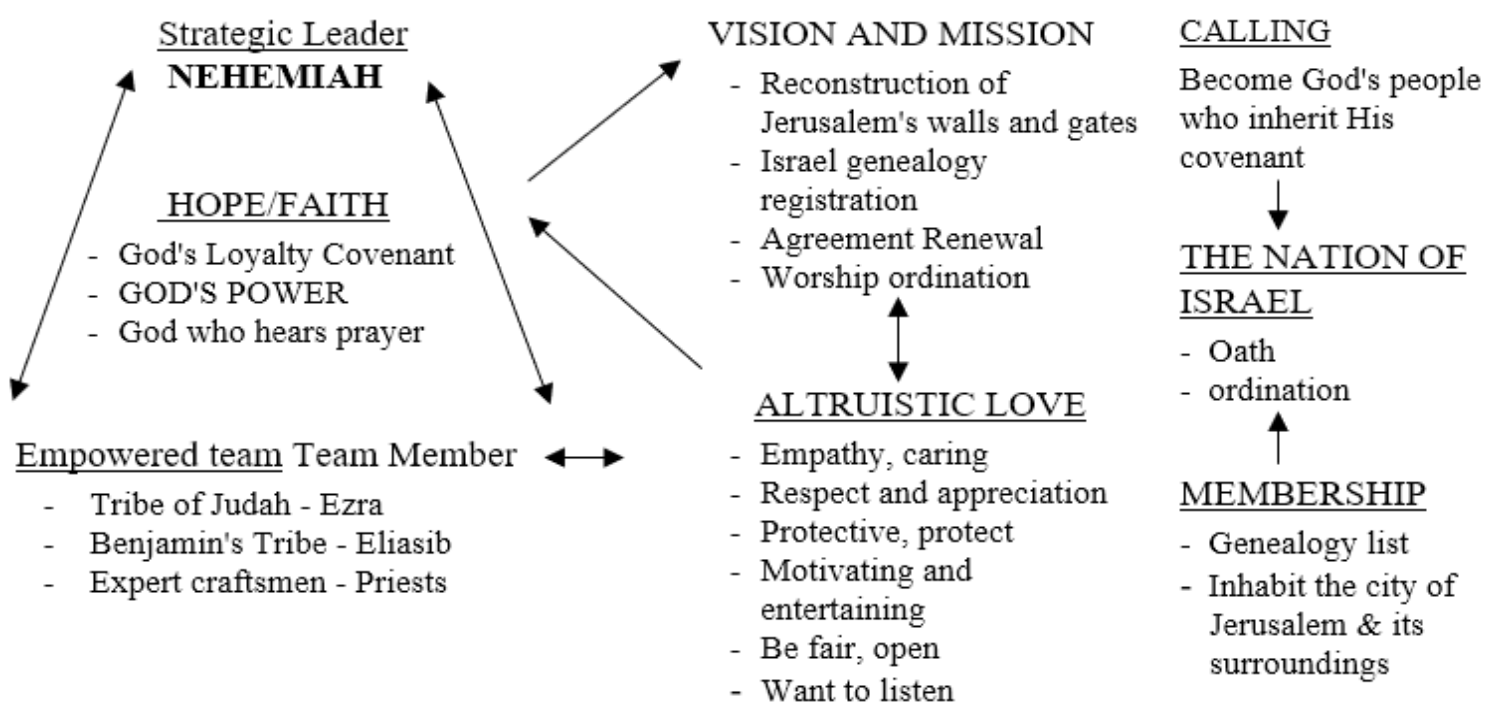

Figure 3. Schematic of Nehemiah's Spiritual Leadership (according to Dr. Fry's model)

\section{Structuralism synchronic review}

In the original Hebrew texts, the books of Ezra and Nehemiah are not separate, but it is quoted from the chastic 
Theological Journal Kerugma

E-ISSN: 2622-1039

P-ISSN: 2621-8038

structure of the book of Nehemiah to show

from Greimas' actantial semantic model. ${ }^{36}$.

the outline of parallel themes. ${ }^{35}$

1. Prayed for his people (Neh 1:1-2:20)

2. Arrangement of work ( $\mathrm{Ne} 3: 1-32)$

3. The opposition's plans thwarted (Ne 4:1-23)

4. Nehemiah deals with oppression $(\mathrm{Ne}$ 5:119)

5. Enemy intrigues are thwarted ( $\mathrm{Ne} 6: 1-19$

6. List of returned exiles (Ne 7:1-72a)

7. Ezra called the people to obey the law (Ne 7:72b-Neh 8:18)

8. National confession (Ne 9:1-37)

9. List of covenants (Neh 10:1-30)

10. Covenants (Ne 10:31-40)

11. The people who lived in and outside Jerusalem (Ne 11:1-36)

12. Dedication of Jerusalem wall (Neh 12:147)

13. Nehemiah's Reformation (Ne 13:1-31)

From the arrangement of the chiastic structure above, it can be concluded that the main theme of the book of Nehemiah is "the renewal of the covenant of the people of Israel" which is accommodated by the restoration of the walls of Jerusalem. The exposition of Nehemiah's leadership model in a transformational review, will adapt the research from John Arthur on the structure of Nehemiah's agreement analysis using Daniel Patte's structural exegesis method

\footnotetext{
${ }^{35}$ Hajime Murai, "Literary Structure ( Chiasm, Chiasmus ) of Book of Ezra and Nehemiah Correspondence Table of Pericopes and Literary Structure," 2021.
}

\footnotetext{
${ }^{36}$ John Arthur, "Reading Nehemiah : A Structural Analysis of Nehemiah's Covenant Renewal Account and Its Place within The Book of Nehemiah," McMaster Divinity College, Hamilton, Ontario - Canada (McMaster Divinity Colege, 2012).
} 
Nehemiah's pre-Reform

Conditions after Nehemiah's

\begin{tabular}{|l|c|c|c|l|}
\hline \multicolumn{1}{|c|}{ Early part } & Paragraph & Theme Relations & Paragraph & \multicolumn{1}{|c|}{ Final half } \\
\hline $\begin{array}{l}\text { 1. Nehemiah prays for his } \\
\text { people (Neh 1:1-Ne 2:20) }\end{array}$ & $1: 8,9$ & $\begin{array}{c}\text { Covenant, wrath } \\
\text { Mosaic Law }\end{array}$ & $13: 1$ & $\begin{array}{l}\text { 13. Nehemiah's Reformation } \\
\text { (Ne 13:1-31) }\end{array}$ \\
\hline 2. Job settings (Neh 3:1-32) & $3: 1$ & $\begin{array}{c}\text { Dedication of the } \\
\text { walls of Jerusalem }\end{array}$ & $12: 27$ & $\begin{array}{l}\text { 12. Dedication of the walls of } \\
\text { Jerusalem (Ne 12:1-47) }\end{array}$ \\
\hline $\begin{array}{l}\text { 3. Enemy plans thwarted } \\
\text { (Ne 4:1-23) }\end{array}$ & $4: 22$ & $\begin{array}{l}\text { People in } \\
\text { Jerusalem }\end{array}$ & $11: 1$ & $\begin{array}{l}\text { 11. People inside and outside } \\
\text { Jerusalem (Ne 11:1-36) }\end{array}$ \\
\hline $\begin{array}{l}\text { 4. Nehemiah deals with } \\
\text { Oppression (Ne 5:1-19) }\end{array}$ & $5: 10$ & $\begin{array}{l}\text { Liberation } \\
\text { from debt }\end{array}$ & $10: 32$ & 10. Covenants (Ne 10:31-40) \\
\hline $\begin{array}{l}\text { 5. Enemy intrigues thwarted } \\
\text { (Ne 6:1-19) }\end{array}$ & $6: 18$ & Oath & $10: 30$ & $\begin{array}{l}\text { 9. List of agreements } \\
\text { (Ne 10:1-30) }\end{array}$ \\
\hline $\begin{array}{l}\text { 6. List of outcasts } \\
\text { who returns (Ne 7:1-72a) }\end{array}$ & - & Israelites & $\begin{array}{l}8 . \text { National recognition } \\
\text { (Ne 9:1-37) }\end{array}$ \\
\hline \multicolumn{7}{|l|}{ 7. Ezra called the Israelites to obey the law (Ne 7:73 - 8:18) } \\
\hline
\end{tabular}

Table 6. Parallel comparison of the chiastic structure of the book of Nehemiah

From the arrangement of the chiastic structure above, it can be concluded that the main theme of the book of Nehemiah is "the renewal of the covenant of the people of Israel" which is accommodated by the restoration of the walls of Jerusalem. The exposition of Nehemiah's leadership model in a transformational review,will adapt the research from John Arthur on the structure of Nehemiah's agreement analysis using Daniel Patte's structural exegesis method from Greimas' actantial semantic model. ${ }^{37}$. Considering that narrative structuralism is suitable to identify categories of roles and deep structures underlie a narrative text. ${ }^{38}$ Greimas actential method assigning six

\footnotetext{
${ }^{37}$ Ibid.

${ }^{38}$ Patte, What Is Structural Exegesis?
}

structural constants labels actantial roles (three binary) which are separate from the characters in the text, namely, subject object, sender - receiver and supporter opponent. In this actential model, there are three categories of axes, namely communication, volition and authorization. In terms of syntagmatic consists of contract syntagmatic (CS), disjunction/conjunction syntagmatic (DS) and performance syntagmatic (SP) which is further divided into aspects. Then Jean Calloud compiled the structure of the syntagmatic narrative analysis into a list of canonical narrative functions ${ }^{39}$. 


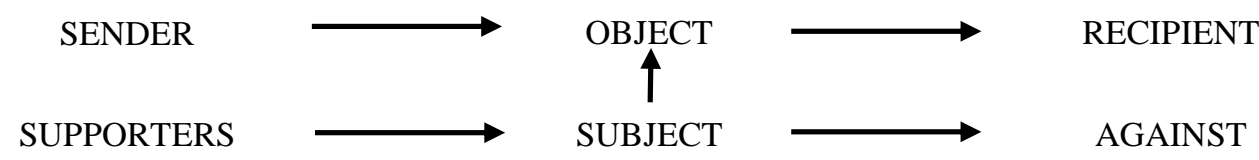

Three Syntagm Categories:

Contract Syntagm (CS)

- CS 1 Statement of mandate vs. acceptance

- CS 2 Statement of communication vs. reception

Disjunction/Conjunction Syntagm (DC)

- DC 1 departure vs arrival

- DC 2 farewell vs encounter

Performance Syntagm (PS)

- PS 1 Statement of confrontation

- PS 2 Statement of dominance or submission

- PS 3 Attribution statement

Figure 4. Schematic of Greimas - Calloud . actantial model

$\underline{\text { SENDER }}$

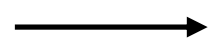

- Sequence I: Artaxerxes

- Sequence II: God

\section{SUPPORTERS}

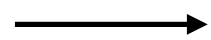

- Hanani

- King Artaxerxes

- Asaf

- The Israelites built the walls

- Genealogy list

- Ezra, Eliashib, priests, Levites

- Torah

- Joy from God

- Action: eat, drink

- Obedience, sense of nationality

- Tradition
Three categories of axes:

- Communication

- Volition (will)

- Authorization (power) 
Sequence I: Construction of the walls of Jerusalem (Neh 1:1 - 7:4)

Key Verse: Neh 2:20 God of the heavens, He is the One who made us successful

Sequence II: Nehemiah's Renewal of the Covenant (Neh 7:5 - 12:43)

Key verse: Neh 7:5 So my God put in my heart a plan

\begin{tabular}{l|l|}
\hline \multicolumn{1}{|c|}{ Chiastic Structure (Table 2) } & Greimas Actential Sequence Schematic \\
\hline Sequence I & \\
\hline $\begin{array}{l}\text { 1 Nehemiah prays for his people } \\
\text { (Ne 1:1-Ne 2:20) }\end{array}$ & $\begin{array}{l}\text { CS 1 Mandate vs Acceptance } \\
\text { Letter from King Artaxerxes - The regents and Asaph the gardener }\end{array}$
\end{tabular}

2 Job settings (Ne 3:1-32)

3 Enemy plans thwarted

(Ne 4:1-23)

4 Nehemiah deals with

Oppression (Ne 5:1-19)

5 Enemy intrigues thwarted

(Ne 6:1-19)

CS 2 Communication vs Listening

News from Hanani - Nehemiah hears (1:2-4)

Nehemiah's request - king Artaxerxes grants (1:3-8)

Nehemiah speaks to the Israelites about building (2:17-18)

DC 1 Depart vs Arrive

Nehemiah departs from castle of Susan - arrives across the Euphrates (2:9); Nehemiah arrives in Jerusalem, investigates the walls (2:13-17)

DC 2 Conjunction vs Disjunction

Israelite leaders ready to build $(2: 18)$

PS 1 Confrontation Function

Contradictions of Sanballat and Tobiah $(2: 10,19 ; 4: 1-8 ; 6: 1-14)$

Leaders blackmail the Israelites (5:5-13)

Sanballat slanders Nehemiah by bribing the false prophet (6:5-14)

The chronological structure is arranged in chronological order (diachronic), while the narrative structure consists of several subsequences with repetitive (synchronous) functions so that in Sequence I the two methods are difficult to align.

PS 2 Authorization Domination Function

Nehemiah speaks to the leader of the Israelites (2:17-18)

PS 3 Attribution Functions (9:1-3)

Nehemiah's petition to God $(1: 5-11,20)$

Eliashib the high priest, priests and brethren build (3:1-32)

Building team working while ready for battle (4:14-23)

Nehemiah appointed regent $(5: 14-19)$

Wall-building work completed $(6: 15)$

Sequence II

6 List of outcasts who

return $(\mathrm{Ne} 7: 1-72 \mathrm{a})$

God gives a plan, Nehemiah accepts (7:5)

CS 2 Communication vs Listening

God's Communication - Nehemiah hears (7:5 and list 7:6-72a)

Ezra Communications - the Israelites heard $(7: 72 b-8: 8)$

7 Ezra called the people of Israel obey the law (Ne 7:73-8:18)

DC 1 Depart vs Arrive

Nehemiah arrives in Jerusalem (8:9)

PS 1 Function: Confrontation

Go, eat, drink, don't be sad $(8: 11)$

PS 2 Function: Authorization domination

8 National confession ( $\mathrm{Ne} 9: 1-37)$

9 List of covenants ( $\mathrm{Ne} \mathrm{10:1-30)}$

10 Covenant (Ne 10:31-40)

11 People inside and outside

Jerusalem (Ne 11:1-36)

12 Dedication of the walls of Jerusalem (Ne 12:1-47)

The Levites tell everyone to be quiet with words $(8: 12)$

Israelites obey (8:13-18)

PS 3 Function: Attribution (9:1-3)

confession \& supplication (9:4-37)

oath \& commitment to God (9:38 -10:39)

Jerusalem repopulation and list (11:1 -12:26)

ordination of the people, the city gate walls of Jerusalem.(12:27-43)

Table 7. Comparison of Chiastic Structural Analysis and Greimas 


\section{Theological and Intertextual Overview}

It is important to note that the province of Judah under Persian control only covered an area of about $1,700 \mathrm{~km} 2$ with a population of about 30,000 in and around Jerusalem. Economically very poor with a high tax burden, socially vulnerable with weak regional boundaries. The return of the Israelite exiles during the time of Ezra and Nehemiah to support the Persian political strategy against Egypt $^{40}$ So politically for the Persian empire, the return of Ezra and Nehemiah who was considered pro-Persian was not to rebuild the Davidic kingdom, as evidenced by Zerubbabel, the Zionite, David then disappeared from the scene without being known. For the Israelites after returning from exile, the vision of the Davidic royal family was seen as an eschatological rather than a political reality. Even though Nehemiah was in Susan's palace as the king's cupbearer, he still set his sights on God's promise to Israel (Neh 1:4-11). (Cf. John 15:19).

Sanballat againstNehemiah's plan, was that the remnant of the descendants of the northern Israelites who did not go into the Babylonian exile, separated from the

\footnotetext{
${ }^{40}$ Oded Lipschits, “'Demographic Changes in Judah between the Seventh and Fifth Centuries BCE', in O. Lipschits \& J. Blenkinsopp (Eds.), Judah and the Judaeans in the Neo-Babylonian Period" (Winona Lake: Eisenbrauns, 2003).
}

family and accommodated intermarriage with the natives of Canaan. He built a rival temple as a force to unite the inhabitants of Samaria, installed Eliashib's grandson as high priest and married him to his daughter because the Levites had moved to Judah. Sanballat was the one who had accommodated mixed marriages for the Israelites, thereby tarnishing God's covenant out of sheer greed for political power. ${ }^{41}$ Then God through Nehemiah was assisted byEzra to reform and renew through the reading of the book of Moses, so that the Israelites repented and then they separated themselves from all foreigners and their descendants (Neh 9:2, 28-30; 13:23-27).The following is an ethical attitude assessment based on the spiritual leadership theory of Dr. Fry.

\footnotetext{
${ }^{41}$ Bob Wielenga, "Renewal and Reconstruction: Holy Writ in Ezra-Nehemiah - A Missional Reading," In die Skriflig/In Luce Verbi 47, no. 1 (2013): 1-9.
} 


\begin{tabular}{|l|c|c|c|l|}
\hline \multicolumn{2}{|l|}{ Nehemiah (theological) } & Ethical Aspects of Transformational Leadership & \multicolumn{2}{l|}{ Sanballat (syncretical) } \\
\hline $2: 5-9 ; 17-18 ; 4: 9$ & $\sqrt{ }$ & Goals \&ways of working do not violate moral ethics & - & $4: 1,7-8 ; 6: 1,2-7$ \\
\hline $5: 14-19 ; 13: 12$ & $\sqrt{ }$ & Incentives/sanctions force or suppress conscience & - & $6: 12 ; 13: 7-11 ; 13: 28$ \\
\hline $7: 5-73 ;$ ps 9-10 & $\sqrt{ }$ & Sincere towards everyone regardless of position & - & $2: 10 ; 19$ \\
\hline $\begin{array}{l}\text { 5:1-13; 7:65; ps 8- } \\
10\end{array}$ & $\sqrt{ }$ & Conflict resolution and impartial claims & - & $6: 12$ \\
\hline 4:23; ps 8-9 & $\sqrt{ }$ & Not dominating and manipulating & - & $6: 8-12$ \\
\hline $3: 1-32 ; 4: 6,13-18$ & $\sqrt{ }$ & Empowering and truly actualizing & - & $6: 14,17-19$ \\
\hline $2: 17-18 ; 4: 19-23$ & $\sqrt{ }$ & Open and transparent leadership program & - & $6: 2$ \\
\hline $4: 21-22 ; 9: 38-12: 47$ & $\sqrt{ }$ & Appreciate dignity and accept personal talent & - & $4: 1-3$ \\
\hline
\end{tabular}

Table.8 Nehemiah vs Sanballat Ethical Values Comparison

Nehemiah's theological vision and mission was given from God, he received God's own mandate and authorization. In carrying out this mission, heremain obedient to the procedures of a sovereign government, yet fully question and depend on God's omnipotence. In the prayers of confession to God, Nehemiah mentions God's promise, His omnipotence and mercy as written in the Torah of Moses. God's promise theologically refers to the

promise of Abraham, Isaac and Jacob and includes three things namely, the promise of descendants, the promised land and by which all the peoples of the earth will be blessed (Gen 12:1-3; 15:5-7, 18; 17:1 -14). In particular the Bible records the "seed" $\square$ zera ' which theologically refers to the messianic prophecies of the Bible that can be proven based on the history of the birth and genealogy of Jesus Christ compared to intertextual verses from the Bible.

\begin{tabular}{|l|l|l|l|l|l|l|l|}
\hline $\begin{array}{l}\text { Descendants } \\
\text { of women }\end{array}$ & $\begin{array}{l}\text { Semitic } \\
\text { Adam's set }\end{array}$ & $\begin{array}{l}\text { Abraham, } \\
\text { Isaac, Jacob }\end{array}$ & $\begin{array}{l}\text { Tribe of } \\
\text { Judah }\end{array}$ & $\begin{array}{l}\text { throne } \\
\text { David's family }\end{array}$ & $\begin{array}{l}\text { Christ the } \\
\text { Messiah }\end{array}$ & $\begin{array}{l}\text { God's } \\
\text { Church }\end{array}$ \\
\hline Gen 3:15 & Gen 5:3 & $\begin{array}{l}\text { Genesis 12- } \\
35\end{array}$ & Gen 49:10 & 2 Sam 7:14-16 & $\begin{array}{l}\text { Luke 1:27; } \\
3: 23\end{array}$ & John 1:12 \\
\hline
\end{tabular}

Table 9. Chronology of theological review based on messianic prophecy

God revealed His plan to Nehemiah to record the genealogy of the Israelites while carrying out the covenant renewal and ordination of worship in the temple was part of God's eternal plan. God prepared the Christ who existed before the foundation of the world to be born from the seed of the woman and the genealogy of 
the covenant people as the way of salvation for mankind (Cf. I Pet. 1:20; I Cor. 2:7). In Christ the Gentiles found the way of salvation and fulfilled the Abrahamic covenant. Where through Christ all the families of the earth will receive blessings, not just outward blessings but spiritual blessings, namely salvation in Christ as children of God (John 1:2; Eph 1:4-5; Colossians 2:9-10; I Cor 6:17, I Peter 2:9; I John 3:1).

\section{CONCLUSION}

The research and discussion shows that spiritual leadership theory and transformational (and transactional) leadership theory are synchronous, relevant and proven to be adopted from Bible values and principles.which in this case is Nehemiah's leadership model. But in secular application, it sided with the universal concept by eliminating the God of the Bible and replacing it with a "god" who was identified as a greater and more powerful force than man, in whom man put his hope and faith. The secular application distinguishes between humanistic spirit related to the social sciences and religiosity which is considered to be traditionally bound by various liturgies and fragmented so that it cannot accommodate its universal application.
Nehemiah's leadership exposition based on historical review, textual, theological and intertextual from the book of Nehemiah shows that Nehemiah's leadership comes from the God of the Bible who is the Subject of the whole vision, mission, power, control, plan, will and everything. (Cf. Rom. 11:33-36). So that the church and Christians as heirs and holders of God's mandate are obliged to apply the values and principles of biblical leadership in God's real global plan. It is sad if the christians and churches has unwittingly acted syncretistically similar to Sanballat who tried to uphold the Jewish tradition by building a temple on Mount Gerizim, but lived in a mixture and had a mentality and behavior that did not reflect biblical values. On the other hand, Nehemiah's leadership shows how to live ethically and have high moral values because of faith and based on the fear of God. Thus, Christians and God's church are able to be witnesses and carry out the cultural mandate and salvation mandate from God.

Code : It is interesting to note that theoretically, science and the field of theology are identical in structure, the difference is that the theory of science is subject to empirical evidence, while the theological model is accepted based on 
faith as fixed, unchanging and true (Fry 2003). This is often an obstacle in theological scientific writing because the majority view that science is not the right instrument to prove the truth in areas where no theory testing is carried out, including in the field of human experience that relies on faith. Because of faith, there is no need to examine the causal relationship that occurs, and leave various questions regarding the field of spirituality and its application to theology. While the scope of applied theology is related to the early social sciences such as anthropology, sociology, psychology and then expanded to the fields of organization, human resources, leadership and even business and management, so that the research approach method needs to be designed more holistically.

\section{REFERENCES}

[1] Allen, Charles Livingstone. 1972. The Miracle of Love. Grand Rapids: Fleming H Revell Co.

[2] Ancona, Deborah, Thomas A. Kochan, Maureen Scully, John Van Maanen, and D. Eleanor Westney. 2009. Managing for the Future Organizational Behavior \& Processes. Routledge. 3rd ed. Mason,. $\mathrm{OH}$ : South Western Cengage Learning. [3] Arthur, John. 2012. "Reading Nehemiah: A
Structural Analysis of Nehemiah's

Covenant Renewal Account and Its Place within The Book of Nehemiah."

McMaster Divinity College, Hamilton,

Ontario - Canada. McMaster Divinity

College.

[4] Bass, Bernard M., Bruce J. Avolio, Dong I. Jung, and Yair Berson. 2003. "Predicting Unit Performance by Assessing Transformational and Transactional Leadership.” Journal of Applied Psychology 88, no. 2: 207-18. https://doi.org/10.1037/00219010.88.2.207.

[5] Bass, Bernard M, and Ronald E Riggio. 2006. Transformational Leadership. 2nd ed. New Jersey, London: Lawrence Erlbaum Associates.

[6] Blackaby, Henry T, and Richard Blackaby. 2006. Spiritual Leadership - Moving People On To God's Agenda. Nashville, Tennessee.

[7] Chia, P. S., \& Juanda, J. (2019). A Textual Criticism and Lexical Analysis of Isaiah 62. Journal DIDASKALIA, 2(2), 8-13.

[8] Covey, Stephen R. 1991. Principle-

Centered Leadership. New York: Rosetta Books.

[9] _ 2004. The Seven Habits of Highly Effective People. New York: Free Press.

[10] Daft, Richard L. 2008. The Leadership Experience. 4th ed. Mason, $\mathrm{OH}$ :

Thomson South-Western.

[11] Daft, Richard L, and Robert H Lengel. 2000. Fusion Leadership: Unlocking the Subtle Forces That Change People and 
Organizations. Oakland, CA: Berrett-

Koehler Publisher.

[12] Fry, Louis W. 2003. "Toward a Theory of Spiritual Leadership.” Leadership

Quarterly 14, no. 6: 693-727. https://doi.org/10.1016/j.leaqua.2003.09.0 01.

[13] Geisler, Norman L., and RC Sproul. 2013. Explaining Biblical Inerrancy: Official Commentary on the ICBI Statements. Matthews, NC: Bastion Books. http://bastionbooks.com/shop/explainingi cbi/.

[14] Greenleaf, Robert K. 2008. The Servant as Leader. Westfield, IN: The Greenleaf Center.

[15] Greimas, Algirdas Julien. 1987. On Meaning: Selected Writings in Semiotic Theory. Minneapolis: The University of Minnesota Press.

[16] Hays, J Daniel. 2016. The Temple and the Tabernacle. A Study of God's Dwelling Places from Genesis to Revelation. Grand Rapids, MI: Baker Books.

[17] Lipschits, Oded. 2003. “'Demographic Changes in Judah between the Seventh and Fifth Centuries BCE', in O. Lipschits \& J. Blenkinsopp (Eds.), Judah and the Judaeans in the Neo-Babylonian Period." in . Winona Lake: Eisenbrauns.

[18] Losey, Christopher R. 2012. The Portrait of a Godly Leader. Creekside, California: Institute of Disciple Making.

[19] MacArthur, John. 1998. In the Footsteps of Faith: Lessons from the Lives of Great Men and Women of the Bible. California:
Crossway Books.

[20] Moxley, Russ S. 1999. Leadership and Spirit. San Francisco, CA: Jossey-Bass.

[21] Murai, Hajime. 2021. "Literary Structure ( Chiasm, Chiasmus ) of Book of Ezra and Nehemiah Correspondence Table of Pericopes and Literary Structure." http://www.bible.literarystructure.info/bib le/15_EzraNehemiah_e.html.

[22] Patte, Daniel. 1979. What Is Structural Exegesis? 2nd ed. Philadelphia: Fortress Press.

[23] Sanders, J. Oswald. 1986. Spiritual Leadership. Chicago: Moody Press. https://pubs.acs.org/doi/10.1021/acsami.9 b03822.

[24] Slotnick, Michael D. 1992. "Spiritual Leadership, How Does The Spirit Move You?" Distribution. BS United States Military Academy, West Point, New York.

[25] Smith, Huston. 1991. The World's Religions. 2nd ed. San Francisco: Harper.

[26] Tackett, Del. 2006. "What's a Christian Worldview?" 2006. https://www.focusonthefamily.com/faith/ whats-a-christian-worldview/.

[27] Throntveit, Mark. 1992. Ezra-Nehemiah Interpretation Bible Commentary. Edited by James Luther Mays. Louisville, Ky: John Knox Press.

[28] Wielenga, Bob. 2013. "Renewal and Reconstruction: Holy Writ in EzraNehemiah - A Missional Reading." In Die Skriflig/In Luce Verbi 47, no. 1: 1-9. https://doi.org/10.4102/ids.v47i1.72. 
Theological Journal Kerugma

E-ISSN: 2622-1039

P-ISSN: 2621-8038

[29] Yammarino, Francis J. 1993.

https://doi.org/10.1016/1048-

"Transforming Leadership Studies:

9843(93)90043-S.

Bernard Bass' Leadership and

Performance beyond Expectations." The

Leadership Quarterly 4, no. 3-4: 379-82. 